\title{
RHINOVIRUSES, A(H1N1)V, RSV: The RACE FOR HIVERNAL PANDEMICS, FRANCE 2009-2010
}

\author{
J S Casalegno (jean-sebastien.casalegno@chu-lyon.fr)1,2, M Bouscambert-Duchamp ${ }^{1,2}$, F Morfin ${ }^{1,2}$, B Lina ${ }^{1,2}$, V Escuret ${ }^{1,2}$ \\ 1. Hospices Civils de Lyon, National Influenza Centre, Laboratory of Virology, Lyon, France \\ 2. Université de Lyon, Department of Virology, Lyon, France
}

This article was published on 5 November 2009.

Citation style for this article: Casalegno JS, Bouscambert-Duchamp M, Morfin F, Lina B, Escuret V. Rhinoviruses, A(H1N1)v, RVS: The race for hivernal pandemics, France 20092010. Euro Surveill. 2009;14(44):pii=19390. Available online: http://www.eurosurveillance.org/ViewArticle.aspx?ArticleId=19390

To the editor: The $A(H 1 N 1) v$ circulation in France, like in other European countries (Sweden), is still reported as sporadic. The incidence of $\mathrm{A}(\mathrm{H} 1 \mathrm{~N} 1) \mathrm{v}$ infections monitored in the community by the French National Influenza Centre has remained stable for 6 weeks from week 37 to week 42 (159 cases per 100,000 inhabitants). This is right above the epidemic cut-off of 114 cases per 100,000 inhabitants two months after the start of the new school year. This delay in the $A(H 1 N 1) v$ outbreak expansion is puzzling. At the same time, we report a high rhinovirus activity (34.5\% of samples positive for rhinovirus) in the community and in the hospital (unpublished data).

It has been postulated by $\mathrm{A}$. Linde et al. [1] that the viral interaction between the $\mathrm{A}(\mathrm{H} 1 \mathrm{~N} 1) \mathrm{v}$ and the rhinoviruses may explain partly this delay. This is an interesting hypothesis, indeed it is well known $[2,3]$ that during winter, rhinovirus, respiratory syncytial virus (RSV) and influenza viruses epidemic peaks happen one after the other and occasionally overlap. The seasonal epidemiology of influenza is surely dependent on weather conditions such as low relative humidity and cold temperature [4]. These features were observed in our laboratory last winter.

Indeed, during the 2008-2009 winter, our laboratory analysed samples from the paediatric hospital of Lyon. The laboratory diagnosis was based on cellular culture for RSV and influenza

\section{F I G U R E}

Number of laboratory confirmed cases of rhinovirus, RSV and influenza A during autumn and winter 2008-2009, Lyon

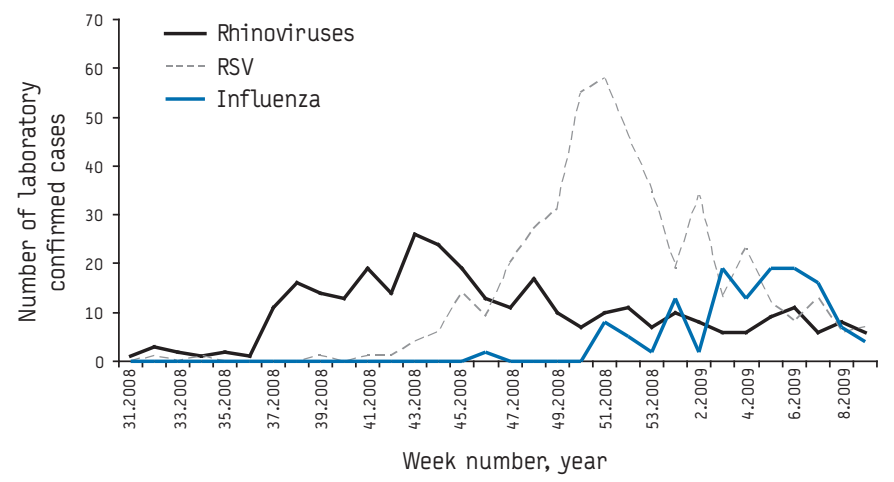

viruses detection and on specific RT-PCR technique for the influenza and the rhinoviruses detection. Between week 31 of 2008 and week 9 of 2009, 6516 respiratory samples (nasal swabs or nasopharyngeal aspirates) were analysed (culture and PCR) in our laboratory. The number of confirmed rhinoviruses, RSV and Influenza A viruses is reported week by week in the Figure.

This year, rhinovirus detection started on week 37 , peaked on week 40 and decreased on week 43. At that moment, we can report the first detection of RSV and an increasing activity of $A(H 1 N 1) v$. Regarding what was observed during last winter on the circulation of rhinovirus, RSV and $A(H 3 N 2)$ virus, it will be of much interest to follow the impact of the $A(H 1 N 1) v$ pandemic on the coming RSV peak. In other words, which respiratory virus between RSV or $A(H 1 N 1) v$, will win the race for second place?

\section{References}

1. Linde A, Rotzén-Östlund M, Zweygberg-Wirgart B, Rubinova S, Brytting M. Does viral inteference affect spread of influenza? Eurosurveill. 2009;14(40): pii: 19354. Available from: www.eurosurveillance.org/ViewArticle. aspx?ArticleId $=19354$

2. Anestad G. Interference between outbreaks of respiratory syncytial virus and influenza virus infection. Lancet. 1982;1(8270):502.

3. Lina B, Valette M, Foray S, Luciani J, Stagnara J, See DM, et al. Surveillance of community-acquired viral infections due to respiratory viruses in RhoneAlpes (France) during winter 1994 to 1995. J Clin Microbiol. 1996;34(12):3007-11.

4. Lowen A C, Mubareka S, Steel J, Palese P. Influenza virus transmission in dependent on relative humidity and temperature. PLoS Pathogen. 2007; $3(10): 1470-6$. 